\title{
ELEMENTARY SCHOOL LEARNING SYSTEM IN TRENGGALEK DURING THE COVID 19 PANDEMIC
}

\author{
Submitted: \\ 10 Juli 2021 \\ Accepted: \\ 12 Desember 2021 \\ Published: \\ 31 Januari 2022
}

\author{
Dhenisa Nur Rahmadhani*1, Putri Eka Rahayu², Rian \\ Damariswara ${ }^{3}$. \\ rd996023@gmail.com¹, ekarahayuputri9@gmail.com², \\ riandamar08@unpkediri.ac.id ${ }^{3}$ \\ *Corresponding Author
}

\begin{abstract}
This article is based on finding out systematic learning in elementary school during the COVID-19 pandemic in the Trenggalek area. The main target points are teachers, guardians, and elementary students regarding the process of teaching and learning activities during the covid-19 pandemic. The method used in this study is a qualitative method, namely the method used by asking for some information from several parties concerned directly in accordance with the facts. Giving various questions and statements to the person concerned to receive the answer (Sugiyono, 2014: 142). And the data collection method used is a questionnaire. The data analysis method uses the Miles \& Hubberman (2014) model which includes data reduction, presentation, verification, and conclusions. This study uses interview techniques, so that valid data sources can be obtained. Checking the validity of the data using triangulation of sources, namely teachers, students, and guardians of students. This information was obtained not only from 1 or 2 sources, but from several elementary schools in rural and urban areas such as SDN 2 Margomulyo, SDN 1 Tasikmadu, SDN 2 Sawahan, SDN 1 Ngadisoko, and SDN 1 Trenggalek. The selection of resource persons must also be appropriate, who are good at conveying information which can be proven to be true, which is an important reference in the preparation of this article. The quality of the learning media used to complete important points in order to improve the quality of the article.
\end{abstract}

Keywords: elementary school learning media during the Covid Pandemic 19

\section{INTRODUCTION}

One of the important points in life is learning. Learning can be done in theory or practice and also formally or informally. There are several quotes from scientists about learning.

Another opinion about learning was put forward by Hamalik, namely "Learning is a real change in the elements of words and sentences that undergo changes. Learning outcomes are not from mastery of exercises but changes in behavior." (Hamalik, 2016: $30)$. 
"Quality learning at least places students as quality learning facilitated by quality teachers and a quality learning ecosystem." (Sukakhamad 2009: 354).

So, learning is a process that is used to achieve the desired goals in thssse learning process. And to be able to achieve these learning objectives, an effective learning process is needed in it, such as using quality learning media.

The purpose of learning is to organize, educate, and understand in order to build a character in students who are diligent, smart, disciplined and obedient. Especially during this pandemic. where the government recommends that each learning process must implement good and correct health protocols. And without us realizing that environmental conditions can affect the learning process.

During the pandemic, the recommendation for online learning activities (non-face to face) must be applied in the learning process with students. It can be seen that the online learning process is not as effective as the direct learning process (face to face). In order for the learning process to continue to achieve the desired goals or objectives, one must be able to choose and sort out effective methods or media to improve the quality of a learning process.

One of them is able to collaborate with various methods, including teachers acting as remote tutors, students as media who can learn online with the guidance of teachers and parents (Lase, 2019). Parents function as substitute tutors for teachers in schools who monitor children's learning progress at home (Kurniawan, 2018).

The most important thing that is needed in this learning is communication between teachers, students, and parents. Because that way it will be easier to achieve the desired learning goals for students during the current pandemic. In this study, an observation of learning in Trenggalek during the Pandemic.

Based on the results of observations that have been made at the elementary school in Trenggalek in the learning process, implementing teaching and learning activities from home during the covid-19 pandemic. Describes the learning system and methods adopted by elementary school in Trenggalek during the covid-19 pandemic. It also summarizes several aspects related to the learning process in the area. 


\section{METHOD}

The research method uses a phenomenological type of qualitative research approach, namely research conducted in natural conditions or directly to data sources and researchers (Sugiyono, 2016). Instrument validation needs to be done with the aim of obtaining valid data in research (Arikunto, 2014). This study used a data collection instrument, namely a questionnaire. Questionnaire is a collection of written questions that are used to obtain information from respondents about the questions given by the researcher. The questionnaire process was carried out by personally meeting the resource persons, namely elementary school teachers, parents, and students in Trenggalek. The selection of resource persons in this study was carried out evenly. This means that the sources are divided from villages and cities in Trenggalek so that the data sources obtained can be valid. Because basically learning in the village and in the city is quite different. Sources of data from the village included 5 elementary school teachers, 6 guardians, and 3 students from different schools. Meanwhile, from the city there are 4 elementary school teachers, 5 guardians, and 3 students from different elementary schools.

The questioning was conducted by means of question and answer related to learning during the Covid 19 pandemic. The data analysis technique used the Miles \& Huberman (2014) model, which included data reduction, data presentation, verification and conclusions. Checking the validity of the data using triangulation of sources, namely teachers, students, and guardians of students who come from villages and cities. Triangulation is checking data from various sources by checking the validity of the data using something other than the data for checking purposes or as data comparisons (Moleong, 2011).

\section{Results}

The following will be presented the data from the questionnaire to the three sources, namely teachers, students, and parents of elementary students in Psychology: 
Table 1. Results of Teaching and Learning Activities Questionnaire on

Pandemic period Covid 19

\begin{tabular}{|c|c|c|c|c|c|c|}
\hline \multirow[b]{2}{*}{ No. } & \multirow[b]{2}{*}{ Indicator } & \multirow[b]{2}{*}{ Aspects Investigated } & \multicolumn{4}{|c|}{ response } \\
\hline & & & $\begin{array}{c}\text { Teache } \\
\mathrm{r}\end{array}$ & $\begin{array}{c}\text { Stude } \\
\text { nt }\end{array}$ & $\begin{array}{c}\text { Guardia } \\
\text { n } \\
\text { pupil }\end{array}$ & Description \\
\hline 1. & System learning & $\begin{array}{l}\text { - Provide a statement } \\
\text { regarding the learning } \\
\text { system of the } \\
\text { Trenggalek education } \\
\text { office. } \\
\text { - Providing RPP / book } \\
\text { pandemic curriculum } \\
\text { module covid } 19\end{array}$ & $\sqrt{ } \sqrt{ } \sqrt{ }$ & & $\sqrt{ }$ & Credible \\
\hline 2. & $\begin{array}{l}\text { Implementation of } \\
\text { teaching }\end{array}$ & $\begin{array}{l}\text { The use of } \\
\text { educational } \\
\text { applications (Wa } \\
\text { Group, google } \\
\text { classroom, and video } \\
\text { calls) } \\
\text { Establish a study } \\
\text { group in the works of } \\
\text { art. } \\
\end{array}$ & $\sqrt{ } \sqrt{ } \sqrt{ }$ & & $\sqrt{ }$ & Credible \\
\hline 3. & $\begin{array}{l}\text { Evaluation of } \\
\text { learning }\end{array}$ & $\begin{array}{l}\text { Filming on the results } \\
\text { of students' learning } \\
\text { - Tasks to quiz / test of } \\
\text { both groups or } \\
\text { independent } \\
\text { - Monitoring of } \\
\text { progress every week } \\
\text { on student learning }\end{array}$ & & & $\sqrt{ } \sqrt{ } \sqrt{ }$ & Credible \\
\hline & & & & & & Credible \\
\hline
\end{tabular}

Source: Interview against informants

Based on Table 1, the results of questionnaires learning activities during the pandemic covid 19 as follows:

1. From the aspect of the learning system the Trenggalek Educational Institution stated that: as an educational institution in Trenggalek, it has the responsibility to regulate and monitor the learning process of Elementary School in Trenggalek. The institution provides directions to elementary school educators to conduct independent learning at home/online during the COVID-19 pandemic. Not only providing direction, but the service also pays more attention to how the online learning process runs. In a way, every month the institution visits each elementary school in Trenggalek in turn. This visit aims to review the work of educators in the online learning process. The 
agency asked for several reports related to online learning from each grade 1-6 elementary school teacher. The report is in the form of online learning data.

2. Aspects seen from the curriculum module book and lesson plans for learning during the covid-19 pandemic: RPP is an important part of a learning process in elementary school. RPP is made by teacher educators with reference to the syllabus from the government, so they can prepare RPP. The learning process will run smoothly if the teacher applies learning in accordance with the lesson plans made. RPP includes a series of learning procedures by covering a series of behaviors that teachers need to do to students and several activities that can be carried out in order to achieve the goals and benefits of all potential in learning.

3. Aspects seen from the implementation of learning through the use of educational applications: In this aspect, the use of educational applications plays an important role in the online learning process during the covid-19 pandemic. The use of the WhatsApp group application is more dominant in the learning process. This happens because WhatsApp users are already evenly distributed in the community, and it makes online learning easier. Google Classroom is used by several elementary schools in the city from grades 5-6. This application occurs because according to the teacher educators, grade 5-6 students are already able to access the application. During certain lessons, such as questions and answers, the teacher usually makes video calls to students to carry out the questions and answers. Not only for questions and answers, but also to find out students' understanding of the material presented. Of the three applications according to teachers, parents and students are more likely to choose WhatsApp Groups as an educational application to support online learning during the Covid-19 period.

4. Aspects seen from group formation in art learning: In forming groups, students are expected to be easier and able to work on making works of art. And students are able to express opinions rationally about the works of art. Based on the description in the field notes, it is explained that the teacher forms groups to help students in terms of discussing to achieve a learning process. However, teachers cannot directly monitor the group discussion process conducted by students, and teachers cannot observe how active students are in making works of art. 
5. Aspects seen from taking pictures on the results of student learning activities: In this aspect, it is recommended that the guardians of students help the process of student learning activities. By taking pictures of students' work, in the form of answer sheets for the questions given. Taking this picture is also to support the report to the teacher. According to the results of field notes, it was explained that the pictures sent by students as learning reports were very helpful for teachers in terms of making reports on learning outcomes during the covid-19 pandemic. And by taking pictures the teacher is also able to know the results of the work given.

6. Aspects seen from giving quizzes/exam assignments either in groups or independently: In this aspect, giving assignments either in groups or independently runs in a credible manner. This means that teachers, students and parents can contribute properly and effectively. In delivering assignments, the teacher does not only give questions, but also in the form of an illustration so that students are able to understand and be able to carry out the exam well given by the teacher.

7. Aspects seen from monitoring the progress of learning every week for students: In this aspect, monitoring is a component of a teaching and learning strategy that functions and plays an important role. Monitoring is carried out as one of the teaching and learning processes that is carried out once a week by the teacher in order to find out how far the understanding received by students is. The teacher monitors by going directly to the field, by making visits to each student's home. Of course with the implementation of health protocols.

\section{DISCUSSION}

This research has produced several aspects that have been applied by teachers, students and elementary school guardians during learning in the COVID-19 pandemic in Trenggalek. In aspect 1 the results are credible with a statement of the elementary school learning system from the educational institution. This statement is an online learning as a substitute for face-to-face in order to avoid the spread of the covid-19 virus. "Learning activities are still carried out online and cannot do face-to-face learning until conditions allow" (Zainab 2021). The educational institution recommends that teachers must be able to properly control the learning process during the pandemic and that the parents of students also participate in this online learning. With the participation of parents in online 
learning, it is hoped that it will help students to better understand the learning material. The educational institution also monitors elementary schools in Trenggalek, this aims to review how active teachers are in the online teaching and learning process. The teacher provides several reports related to evidence of student learning at home in the form of photos/videos of student assignments.

In the second aspect, the results are credible by providing RPP/books for the COVID-19 pandemic curriculum module. RPP is one of the learning activities owned by the teacher as a learning guide in the classroom. RPP is made for the purpose of regulating the implementation of more directed learning in accordance with the predetermined KD (Mulyasa, 2015). In preparing the RPP, the teacher must be able to master the theory and elements in the RPP. RPP is useful for predicting learning success, utilizing learning resources optimally, organizing learning activities systematically, and as a teacher guide. During the COVID-19 pandemic, it was different from before the Covid-19 pandemic. During the pandemic the RPP also underwent a change, namely from the K13 curriculum RPP to the 2021 curriculum.

In the third aspect the results were credible with the implementation of learning through the use of educational applications. The learning process during this pandemic is very dependent on educational applications. Like WhatsApp Grub and Google Classroom, the use of this application itself has advantages and disadvantages in each application. Like Google Classroom, which is only used by elementary school grades 5 and 6. Because this application is quite complicated for children or elementary school students, its use is only recommended for grades 5 and 6 of elementary school. This Google Classroom is also only known among elementary school students in the city. In rural areas, they have not used the Google Classroom application, only using WhatsApp. Why is that? According to data sources obtained from interviews, elementary school teachers in villages only use WhatsApp for the learning process on the grounds that it is easier, more efficient and can be used in all circles, both adults and small children. "Yes, so that learning does not burden students in providing material or collecting assignments, then only use WhatsApp grub. If you use an application like Google Classroom for a village area that is quite remote, in my opinion, it is quite inconvenient. Moreover, if students or their guardians cannot access it, it will add to the problems in the learning process," said Mrs. Ismawati as an elementary school teacher. To better anticipate the 
understanding of the material and the approach between teachers and students. Teachers have many ways, one of which is by making video calls with several students in turn. This method is used by teachers to carry out a deeper understanding of learning materials and also to increase the closeness of teachers and students during this covid-19 pandemic.

In the fourth aspect, the results are credible with the formation of groups in art learning. The formation of groups in art lessons has become a very common thing. Both in elementary schools in villages and in cities, art lessons are indeed carried out by forming discussion groups. "The formation of this group is only when there is material that involves many people. Such as making handicrafts, dancing, and dramas that involve at least 3 people in making assignments, therefore a discussion group is formed," said Bu Endang as an elementary school teacher. This discussion group was formed only in grades 4-6 SD because the art material in that class was already familiar with dance, drama, and handicrafts. While in grades 1-3 only singing and drawing material, which means there is no need to make groups and can be done individually.

In the fifth aspect, the results are credible by taking pictures of the results of student learning activities. Taking this picture is one of the important things in the learning process during the COVID-19 pandemic. This image includes photos of the results of assignments, photos of the learning process at home, and photos of practical learning activities such as sports. In this aspect, student guardians play an important role in helping to take photos of student activities at home, and controlling the progress of learning at home. Because during the pandemic, parents or guardians of students play an important role in the learning process as a substitute for teachers at home by helping students understand the subject matter. The results of this photo shoot also aim to produce reports on learning outcomes during the COVID-19 pandemic. This report is usually made by the teacher to fulfill the learning requirements given by the education office to the supervising teacher. This report is in the form of an analysis of learning which contains photo evidence of learning outcomes at home.

In the sixth aspect, the results are credible by giving quizzes/exam assignments either in groups or independently. According to Refindasari (2015) giving quizzes or exam assignments in online learning is very important to measure how well students are able to understand the material presented by the supervising teacher. This task/exam is 
part of how to measure the achievement of a learning process that has been carried out. This task / quiz has individual and group systems depending on the learning carried out.

In the seventh aspect, the results are credible by monitoring the learning progress of the students every week. Monitoring is one of the mandatory activities that teachers do once a week. With this monitoring, teachers can evaluate their students directly while still complying with health protocols. According to Kusuma (2020) evaluating is an examination of the strategy implementation process, the learning outcomes that have been achieved, as well as an examination of the suitability of the strategy with the type of learning task at hand.

\section{CONCLUSION}

Based on the results and discussion, it can be concluded that the role of the educational institution for teachers and students is very important in the implementation of the primary school education system during the COVID-19 pandemic. Covering several aspects resulting from the research questionnaire data, the results of the questionnaire on teaching and learning activities include directives from the education office to elementary school educators to carry out independent online learning. The RPP is made with a reference to the syllabus from the government which includes a series of learning procedures. Use of educational applications such as WhatsApp groups and Google classroom. Because according to teacher educators, students in grades 5-6 are able to access the application. The formation of groups with the hope that students will find it easier and able to make fine arts. Monitoring by means of teachers going directly to the field by making visits to each student's home by implementing health protocols.

\section{REFERENCES}

Arikunto, Suharsimi. (2014). Basics of Educational Evaluation (Revised Edition). Jakarta. Earth Literature.

Daheri, M., Juliana, J., Deriwanto, D., \& Amda, AD (2020). The Effectiveness of WhatsApp as an Online Learning Media. Journal of Basicedu, 4(4), 775-783.

Dewi, WAF (2020). The Impact of COVID-19 on the Implementation of Online Learning in Elementary Schools. Educational: Journal of Educational Sciences, 2(1), 5561. 
Harjasuganda, D. (2008). Positive Self-Concept Development in Elementary School Students as the Impact of Application of Feedback in Physical Education Learning Process. In the Journal of Basic Education Number, 9(8), 4-5.

Herliandry, LD, Nurhasanah, Suban, ME, \& Heru, K. (2020). Learning Media Transformation During the Covid-19 Pandemic Period Journal of Educational Technology, 22(1), 65-70.

Irawan, E., Arif, S., Hakim, AR, Fatmahanik, U., Fadly, W., Hadi, S., ... \& Hidayati, N. (2020). Higher Education During a Pandemic: Transformation, Adaptation and Metamorphosis Towards the New Normal. Zahir Publishing.

Kusuma, DA (2020). The Impact of the Implementation of Online Learning on Students' Self-Regulated Learning in Geometry Courses During Distance Learning During the Covid-19 Pandemic. Theorems: Mathematical Theory and Research, 5(2), 169-175.

Lase, D. (2019). Education in the Industrial Revolution Era 4.0. SUNDERMANN: Scientific Journal of Theology, Education, Science, Humanities and Culture,1(1),28-43.

Mar'ah, NK, Rusilowati, A., \& Sumarni, W. (2020). Changes in the Online Learning Process for Elementary School Students. Proceedings of the UNNES Postgraduate National Seminar.

Marsiding, Z. (2021). The Effectiveness of Using Zoom Media on Learning During the Covid-19 Pandemic Scientific Journal of Pranata Edu, 2(1), 33-39.

Moleong (2011) CHAPTER III RESEARCH METHODS A.Research Design Mulyasa. (2015). Teachers in 2013 Curriculum Implementation. Bandung: Rosda (http://www.dostoc.com/does/1991556/4_270228) (Downloaded 23 August 2020)

Oemar Hamalik, Teaching and Learning Process (Jakarta: Rosdakarya Youth 2016) 30 Ramadhani, SP, \& Supena, A. (2020). Parents' and Teachers' Perceptions of Learning During the COVID-19 Pandemic Period on 8-Year-Old Speech Disorder Children at Madrasah Ibtidayah. Journal of Basicedu, 4(4), 1267-1273.

Revindasari, F. (2015). Development of anmoodle-based quiz and material management system interactive and communicative (Doctoral dissertation, State University of Malang). 
Riani, N., \& Handayani, NS (2020). The Impact of Librarian Work Stress During the Covid-19 Pandemic n College Library Services. Fihris: Journal of Library and Information Science,15(1),97-114.

Santoso, DH, \& Santosa, A. (2020). Covid-19 in Various Perspective Review. LPPM Mercubuana.

Sugiono Educational Research Methods Quantitative, Qualitative and R\&D Approaches (Bandung: Alfabeta, 2013)

Sulfemi, W. B. (2019). Teacher's Pedagogic Ability.

Zainab (2021) Trenggalek Magazine, equitable distribution of learning in Trenggalek. 